\title{
Decision support system for selecting sectoral data-bases in studies of the water-energy-agricultural-environmental nexus
}

Sistema de apoio à decisão para seleção de bases de dados setoriais em estudos Nexus água-energia-agriculturameio ambiente

\author{
Cássia Juliana Fernandes Torres ${ }^{1}\left(\mathbb{D}\right.$, Rodrigo Saldanha Xavier da Silva ${ }^{1}$ (), Andrea Souza Fontes ${ }^{2}$ (), Daniel Veras Ribeiro ${ }^{1}$ (D), \\ Yvonilde Dantas Pinto Medeiros ${ }^{1}$ (i)
}

\section{A B S T RA C T}

Obtaining databases to develop multidisciplinary studies in complex intersectoral network systems presents great challenges. Databases often lack compatibility or data standardization because they are organized differently by sector. Therefore, this article aims to propose a Decision Support System (DSS) to assist in the identification, analysis, and selection of sectoral databases to support the development of quantitative studies. The concept of the "Nexus of water, energy, agriculture, and the environment" is used to illustrate the development of the DSS. To this end, a conceptual structure defined in six stages was presented: institutional analysis, definition of alternatives, definition of criteria, analysis of databases, classification matrix, and organization and selection of alternatives. Validation of the proposed DSS was carried out using national-scale databases for the Brazilian context. From the application of DSS in the databases surveyed, it appears that: Brazil does not have interconnected databases, nor does it share databases between sectors; the information is dispersed across a large number of institutions, and includes a multiplicity of spatial and temporal scales, hindering their integration; the adoption of macro-scales, both spatially and temporally, facilitates the integration of the collected information, and the country's sectoral organizational structures tend to hamper the development of systems integrated into complex networks. The proposed DSS allows a better understanding and visualization of possible simplifications and limitations inherent in integrated studies of quantitative scope, minimizes uncertainties, and directs systemic planning and management strategies.

Keywords: intersectoriality; natural resources; integrated management.

\section{R E S U M 0}

A obtenção de bases de dados para auxiliar o desenvolvimento de estudos multidisciplinares em sistemas de redes complexas intersetoriais apresenta grandes desafios devido à falta de compatibilização e nivelamento entre as informações, uma vez que estão segmentadas de diferentes formas nos setores correlacionados. Diante disso, o presente artigo tem por objetivo propor um Sistema de Apoio à Decisão (SAD) para auxiliar na identificação, análise e seleção de bases de dados setoriais, visando subsidiar o desenvolvimento de estudos quantitativos mediante o conceito "Nexus água, energia, agricultura e meio ambiente". Para tanto, foi apresentada uma estrutura conceitual definida em seis etapas: análise institucional, definição das alternativas, definição dos critérios, análise das bases de dados, matriz de classificação, e organização e seleção das alternativas. A validação do SAD proposto foi realizada por meio das bases de dados de âmbito federal presentes no Brasil. Após a aplicação do SAD nas bases de dados levantadas, verifica-se que: até o momento, o Brasil não possui bases de dados interconectados e compartilhados entre diferentes setores; as informações concentram-se em uma grande quantidade de instituições e contemplam uma multiplicidade de escalas espaciais e temporais, dificultando suas interações; a adoção de macroescalas, espacial e temporal, facilita a integração das informações levantadas; e as estruturas organizacionais setoriais do país tendem a inviabilizar o desenvolvimento de sistemas integrados em redes complexas. O SAD proposto permite uma melhor compreensão e visualização de possíveis simplificações e limitações inerentes em estudos integrados, de âmbito quantitativo, minimizando incertezas e direcionando estratégias sistêmicas de planejamento e gestão.

Palavras-chave: intersetorialidade; recursos naturais; gerenciamento integrado.

\footnotetext{
${ }^{1}$ Universidade Federal da Bahia - Salvador (BA), Brazil.

${ }^{2}$ Universidade Federal do Recôncavo da Bahia - Cruz das Almas (BA), Brazil.

Correspondence address: Cássia Juliana Fernandes Torres - Rua Professor Aristides Novis, 2 - Federação - CEP: 40210-630 - Salvador (BA), Brazil. E-mail: torres.cjf@gmail.com

Conflicts of interest: the authors declare that there are no conflicts of interest.

Funding: Coordination for the Improvement of Higher Education Personnel (CAPES).
}

Received on: 08/25/2020. Accepted on: 03/25/2021.

https://doi.org/10.5327/Z21769478897

This is an open access article distributed under the terms of the Creative Commons license. 


\section{Introduction}

The nexus concept refers to the interconnected and interdependent management between the water, energy, agricultural, and environmental sectors. It is based on the good governance of each of these sectors, and provides for the design and implementation of more efficient and sustainable policies and actions (Hoff, 2011; WEF, 2011; Bamwesigye et al., 2019).

The nexus concept was initially promoted in 2008, at the World Economic Forum (2011). It was developed based on the need to better understand the interrelations and interdependencies that exist between the sectors in question so as to better manage them. The initiative came about through the efforts of the "2030 Water Resources Group (WRG)," a group of multinational companies in the food and beverage sector which were concerned about the impacts of the water crisis on their global operations (Leese and Meisch, 2015). The WRG prepared the report, "Water security: the water-food-energy-climate nexus," which directed global attention toward these four main pillars of the world economy and their interrelationships (Bizikova et al., 2013; Leese and Meisch, 2015).

Water is necessary for each stage of energy production, and energy is essential for the functioning of the sanitation sector (Maas et al., 2017; Meldrum et al. 2013; Walker et al., 2014; Chang et al., 2016; Sanders and Masri, 2016). The energy sector is highly vulnerable to changes in water resources, especially those that may result from climate change (Meldrum et al., 2013). Both water and energy are inputs for the agricultural sector (Lawford et al., 2013; Chang et al., 2016; Urbaniec et al., 2017); agricultural products provide bioenergy (Wu and Chiu, 2011; Moioli et al., 2018), and the consumption of all these resources has a negative impact on the environment (Wicaksono et al., 2017).

Through the recognition of these interrelationships and their relevance for the structuring of shared intersectoral management, the "nexus" theme has gained increasing interest in academic literature, as evidenced by the growing body of technical and scientific research (Baleta et al., 2019; Meng et al., 2019; Zhang et al., 2019). The greater level of global interest and visibility that surrounds this theme may be attributable to a lack of natural resource security, increasing climatic imbalances, and the recession of the global economy (Allouche et al., 2015; Leese and Meisch, 2015; Al-Saidi and Elagib, 2017). These factors have prompted the nexus concept to emerge as a new paradigm for the public management of natural resources (Torres, 2020).

Since its emergence, research on the nexus concept can be observed across three thematic areas (Torres et al., 2019):

- qualitative studies that recognize and understand the interactions between the different nexus elements (water, energy, agriculture, climate, land, etc.) in different contexts and across scales;

- quantitative studies that evaluate the interconnections and interdependencies between correlated nexus elements;
- socio-political and economic research that analyzes governance models and public policies to outline the nexus concept in terms of practical issues related to management and planning.

As the authors pointed out, the major challenges for conducting quantitative research are the lack of available data on the water, energy, agricultural, and environmental sectors, and the lack of capable models, methods, and instruments to represent the multiple interactions that exist between them (King and Carbajales-Dale, 2016; Albrecht et al., 2018; Embid and Martín, 2018; Nhamo et al., 2018; Shannak et al., 2018; Mercure et al., 2019).

An ideal model or method to represent the nexus concept must be flexible, dynamic, and interactive; it needs to represent and evaluate the relationships between the systems (water, energy, agriculture, and environment), and it must (Miralles-Wilhelm, 2016):

- consider the management and regulation of these resources;

- assist decision makers in defining planning strategies and integrated sectoral policies;

- allow the development of socioeconomic scenarios;

- subsidize evaluations that consider the trade-offs and synergies between the multiple sectors involved;

- allow analyses that consider the effects of variability in the spatial and temporal scales in the systems considered.

Therefore, integrated databases are required. However, obtaining sufficient data to support integrated research on the nexus concept is complex (Embid and Martin, 2018); information on water, energy, agriculture, and the environment is spread across different institutions, information systems, and documents, and there is no shared and accessible database. Additionally, even when this information exists, it often presents divergences in terms of spatial and temporal scales, and a variety of metrics, thereby making it difficult or prohibitive to conduct analyses due to the lack of compatibility (Eftelioglu et al., 2016; Huckleberry and Potts, 2019).

Dispersed databases that do not integrate information are often a reflection of the independent organizational format that has historically been implemented in public sectors, wherein each entity follows its own strategies, policies, plans, data collection, and actions (Eftelioglu et al., 2016; Embid and Martín, 2018). Due to the multidisciplinary nature of these problems, over time, this independent organizational format has been confronted with the need for studies integrated into complex network systems (WEF, 2011; Hanlon et al., 2013).

According to Lawford (2019), an information service must be shared between the multiple correlated sectors to support a well-structured dialogue that fosters joint planning; the leveling of databases based on the identification of common information needs between them is also essential. This service must be developed through an open access platform supported by joint governance; such a service would 
improve management, planning, and decision-making that involves both the public and private sectors.

In view of this, it is observed that there is a need for research on the existing weaknesses in sectoral databases to analyze the possibilities of carrying out integrated studies that include quantitative assessments of natural resources. The results of this investigation vary according to the reality of each location, and the progress in this area, especially of a quantitative nature, did not occur without the support of databases for its development.

Given the above, this article aimed to propose a Decision Support System (DSS) to assist in the identification, analysis, and selection of sectoral databases. The development of a DSS will support the development of quantitative studies on the "Nexus of water, energy, agriculture, and the environment."

\section{Materials and Methods}

The methodology developed comprises the proposal of a DSS, which is an information management system that analyzes different variables to assist in the decision-making process. In this study, a conceptual structure of the DSS is presented. This is an innovative methodology that has been developed to address the gaps identified in the literature regarding the complexity in obtaining compatible information between the involved sectors proposed in the nexus concept.

The proposed conceptual model follows the organizational logic of multicriteria analysis, where different alternatives are evaluated using multiple criteria. The multicriteria analysis is composed of alternatives, criteria, a classification matrix (checklist), and objectives (goals) of the process (Hajkowicz and Collins, 2007). The structural basis of the model used in the present study builds upon that used by Torres et al. (2021).

In this research, the alternatives represent the sectoral databases and the matrix functions as a checklist (Checklist) that verifies which criteria are present in the alternatives. The methodology was divided into six stages, as shown in Figure 1:

- sectoral analysis;

- identification of the databases;

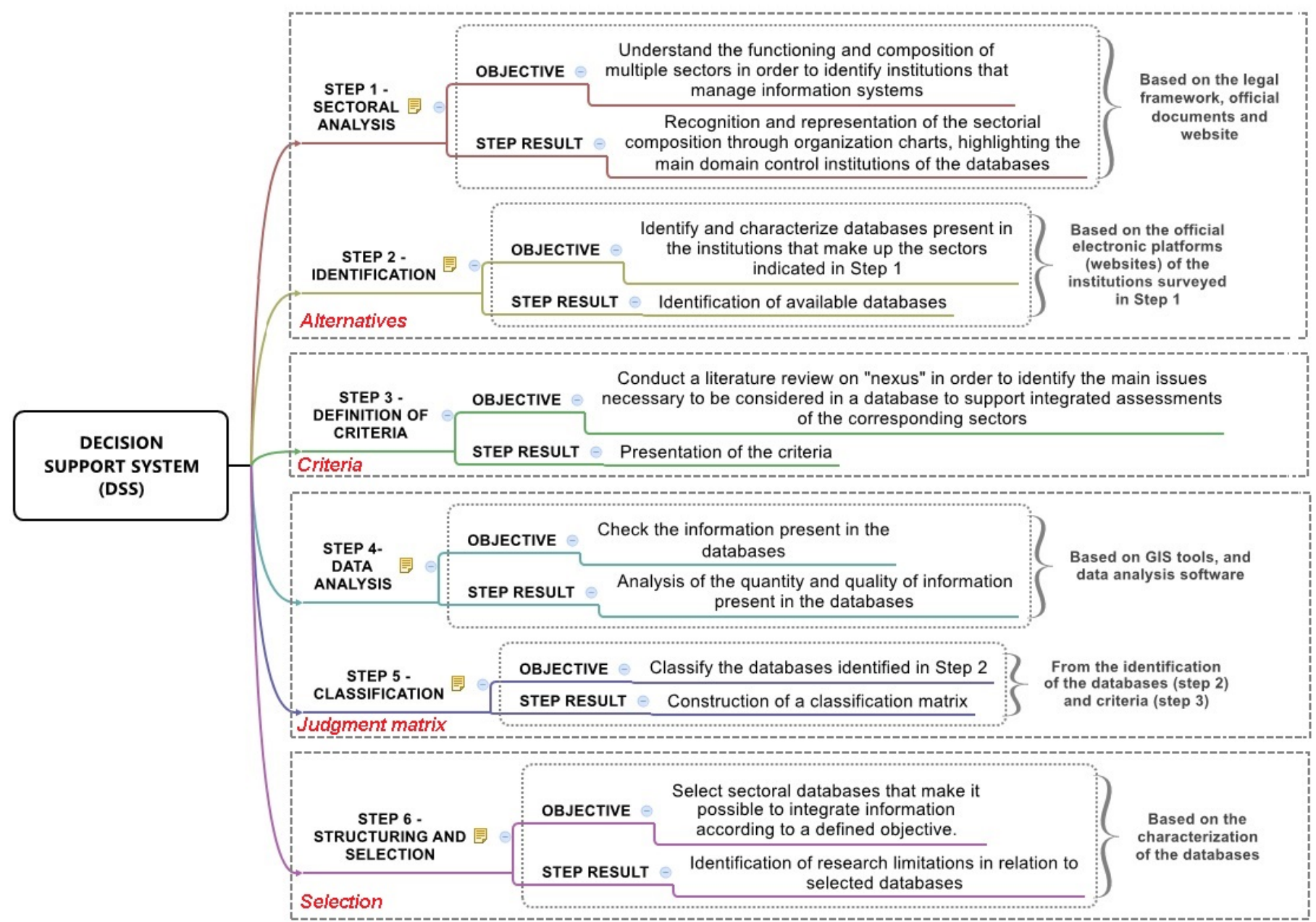

Figure 1 - Conceptual structure of DSS for analysis and selection of databases. 
- definition of the criteria;

- analysis of the databases;

- construction of the classification matrix;

- structuring and selecting databases according to the defined objective.

Step 1: identification of the institutions that make up each sector

The first stage of the DSS consists of an institutional analysis to understand the functioning and composition of the sectors, and to identify and access their databases. For this purpose, the institutional arrangement of the sectors were initially verified through the elaboration of an organization table (hierarchical systematization of the institutions and bodies involved). Once the organizational composition of each sector was identified, the databases were identified, as described in the next section.

The application of the methodology in Federal scale databases was chosen based on two aspects:

- achieving an overview of the information systems of the four sectors in the Brazilian context;

- establishing a hierarchical priority according to the Federal Constitution of 1988: Union, States, and municipalities.

\section{Step 2: identification of alternatives}

This step comprises the identification of the main national databases in the institutions surveyed in the previous step. For this, online consultations were carried out on the official websites of the "National Water Agency (Agência Nacional de Águas - ANA)", "Ministry of Mines and Energy (Ministério de Minas e Energia - MME)" "Ministry of Agriculture, Livestock and Supply (Ministério da Agricultura, Pecuária e Abastecimento - MAPA)," and "Ministry of the Environment (Ministério do Meio Ambiente - MMA)."

In addition to consulting the aforementioned websites, the webpages of the institutions that make up the ministries were also searched, including those of the National Petroleum, Natural Gas and Biofuels Agency (Agência Nacional do Petróleo, Gás Natural e Biocombustíveis ANP), Petrobrás, National Supply Company (Companhia Nacional de Abastecimento - CONAB), Brazilian Institute of the Environment and Renewable Natural Resources (Instituto Brasileiro do Meio Ambiente e dos Recursos Naturais Renováveis - IBAMA).

As a complementary research, the Brazilian Open Data Portal was verified, which functions as a data centralizer in accordance with Decree No. 8.777/2016. According to this decree, government ministries must "promote the publication of data contained in databases of organs and entities of the direct, autarchic and foundational federal public administration in the form of open data" (Brasil, 2016).

In view of this, the federal level databases of the sectors relevant to the nexus concept were selected and investigated. The selection considered the scope of the information to represent the sector in the Brazilian context. In other words, databases that presented information regarding the regional or local scale were ex- cluded from this study. Following this step, the set of criteria for evaluation were defined.

\section{Step 3: defining the criteria}

Aspects for the database analysis were defined to ascertain the possibility of integrating information. The criteria were defined from two points:

- systematic review of the literature, based on Torres et al. (2019), contemplating publications involving the theme "nexus," in the research platforms aiming to identify authors who deal with information systems for integrated evaluations. The main authors who guided these definitions were: WEF (2011), Eftelioglu et al. (2016), Endo et al. (2017), Albrecht et al. (2018), Embid and Martín (2018), Dai et al. (2018), Shannak et al. (2018), and McGrane et al. (2019); - survey of the main aspects to be considered in a database to support integrated assessments of the corresponding sectors.

The highlighted aspects outlined the construction of seven criteria and 27 categories, as shown in Table 1: Criterion 1 (C1) with three categories; Criterion 2 (C2), seven categories; Criterion 3 (C3), three categories; Criterion 4 (C4), six categories; Criterion 5 to Criterion 7, three categories. To facilitate the evaluation of alternatives against the criteria, in the classification matrix, a color palette was defined by a family of criteria categories. It is important to highlight that, from the completion of new bibliographic reviews, other criteria can be included in the list in Table 1, as long as they are characterized and justified.

After defining the criteria listed in Table 1, analyses of some characteristics present in the databases were carried out for a better evaluation of the classification matrix, as shown in the following step.

\section{Step 4: analysis of databases}

In this stage, a careful check is carried out on the quality of the available information. Four main issues are investigated:

- quantity and type of information present;

- divergences from the same information presented in different databases;

- presence of databases that include the monitoring of data from multiple sectors in an interconnected manner (for example, water-energy or energy-agriculture);

- survey of databases from other sectors that include information of interest for the development of integrated studies.

The investigations cited above were defined based on the bibliographic review mentioned in Step 3, as based on the systematic review by Torres et al. (2019).

Geographic information system (GIS) tools and other data analysis tools are essential to support the development of this phase. As a result of this analysis, the construction of the classification matrix for the evaluation of cataloged databases was elaborated. 
Table 1 - Database classification criteria.

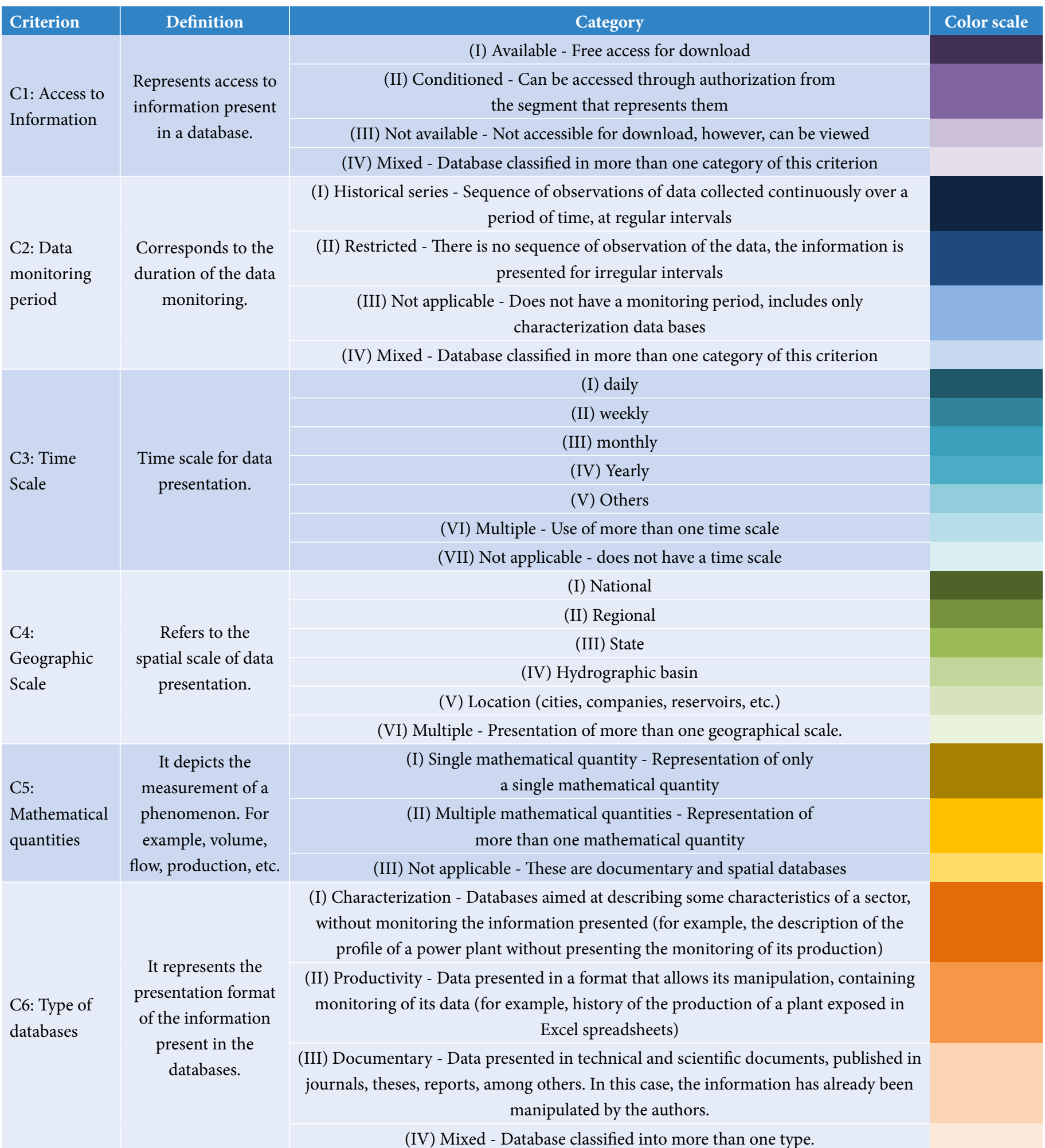

C7:

Spatialization of data
Data georeferencing
(I) Georeferenced

(II) Not georeferenced

(III) Mixed - Databases that include both georeferenced and non-georeferenced information. 


\section{Step 5: classification of alternatives}

The classification of alternatives was carried out by means of matrix analysis. The matrix is composed of rows and columns that vary according to the number of defined criteria and alternatives. In the present study, the lines represent the alternatives and columns, and the categories of the criteria are listed in Table 1 . The matrix functions as a checklist that indicates the categories of criteria present in the database framework. All criteria have the same level of priority, and should be used equally in the evaluation of all alternatives. Thus, filling out the matrix was done using two numeric codes: "1" indicates the presence of the category according to each criterion, and " 0 " indicates its absence.

\section{Step 6: structuring and selecting alternatives}

Structure refers to the elaboration of a selection system complementary to the classification matrix. In this system, the databases are organized by a criterion category session within each sector under study. Two points were considered when completing the proposed structure:

- identification of the criterion category that obtained the least number of databases inserted;

- analysis of the level of relevance of the criterion category for the development of the research.

In the case of a relevant category, which cannot be modified, the databases entered are those selected. However, in the event that this category is not relevant to the study it will be disregarded as a selection parameter, and another category must be analyzed successively until the selection process is closed. Once the DSS was structured, it was validated using federal databases present in Brazil.

\section{Case study: Brazilian context}

In recent years, Brazil has experienced novel uncertainties due to water crises in various regions, and the simultaneous political and economic conflicts that have taken place at the national level. The water crisis that has affected the energy sector in recent years has also impacted other sectors in some parts of the country. This situation has made managers question the real causes of these problems in hopes of determining actions to stabilize this scenario.

Thus, it is pertinent to investigate the country's databases belonging to the main sectors that guide its economy and sustain the well-being of its nation. These investigations tend to corroborate the identification of weaknesses and advances in sectoral databases.

The Federal Constitution of 1988 organizes political and administrative Brazil in entities of the Federation formed by the Union, States (26), Federal District (Distrito Federal - DF), and municipalities $(5,570)$; all are endowed with autonomy in legislative, governmental, tax, and administrative powers (Brasil, 1988). In other words, according to the constitution, all entities of the Federation can legislate, orga- nize, and manage their territory, and the Union should intervene only in situations of disorder that interfere with national integrity. Despite the autonomy of the federated entities, their competencies follow a hierarchy of power, from the greatest to the least powerful: federation, state, DF, and municipality.

The organizational model approved in 1988 is based on the autonomy of federated entities according to their respective competencies. The development of the public sectors in these spheres took place in a segmented and disaggregated way. Their plans, programs, and projects were elaborated largely with no prospect of integration. Today, this course of development reflects the difficulty in planning the articulation between the databases of different sectors due to the diffusion of the integrated management model.

Regarding the water sector, it is the domain of the Union "Lakes, rivers and any water resource in its territory, or that cross more than one State, that serve as limits with other countries or that extend over foreign territory, as well as marginal lands and river beaches" (Brasil, 1988). Water management in Brazil took place in a fragmented way, as each sector carried out its planning in isolation, without participation from municipal governments, water users, and civil society (Abers and Jorge, 2005).

Like the water sector, the energy sector has undergone several institutional changes during the 1970s, 1980s, 1990s, and to the present day. The sector left a monopoly system for free competition in energy generation, commercialization, transmission, and operation distributed between public and private companies. As federal assets, the constitution mentions the potential of hydraulic energy and mineral resources; therefore, the exploitation or use of these resources can only be carried out with authorization or concession from the federal government (Brasil, 1988).

With regard to the agricultural sector, the constitution played a fundamental role in its development by promoting the country's agricultural policies, including rural insurance, agricultural planning, technical assistance, and rural extension (Brasil, 1988).

For the environmental sector, Law No. 6.938/1981 (Brasil, 1981) organized the management of environmental resources at the federal level, and instituted the National Environment System. Complementary Law No. 140/2011 (Brasil, 2011) establishes the instruments and actions of cooperation between the Union, States, DF, and municipalities in administrative actions resulting from the exercise of the common powers established in the constitution. In view of the above, it is observed that despite the great advances that the country has achieved since the adoption of the Federal Constitution, historically, the organizational structures of the public sector have several obstacles and challenges within the scope of integrated intersectoral management.

\section{Results and Discussion}

In Brazil, information on water resources, energy, agriculture, and the environment are segmented into independent databases, managed 
by a large number of institutions at the federal, state, and municipal levels. For the present study, only the main databases in the federal sphere were considered. This section presents the results obtained with the development of the steps that make up the DSS.

\section{Step 1: institutions that make up the sectors under analysis}

For the development of the first stage of the DSS, public policies and legislation relevant to the sectors under analysis in Brazil were used, highlighting federal decisions, provisional measures, and national policies (Brasil, 1981, 1991, 1997a, 1997b, 2019a, 2019b, 2019c, 2019d, 2020). The main institutions, bodies, and collegiate bodies identified in each sector were structured in an organization table (Figure 2), corresponding to the governmental structure in force in the country. The institutions surveyed in the organization table hold the databases of the sectors mentioned at the federal level.

In general, it can be seen that each sector is inserted in a government ministry, and in line with each ministry are the specific secretariats, departments, councils, and bodies.

For the water resources sector, the data generated by the bodies that are part of the National Water Resources Management System (Sistema Nacional de Gerenciamento de Recursos Hídricos - SINGREH) are incorporated into the Water Resources Information System (Sistema Nacional de Informações sobre Recursos Hídricos - SNIRH). The National Water Agency (Agência Nacional de Águas - ANA) is responsible for managing this system in its area of operation (Brasil, 1997a).

In the energy sector, the Energy Research Company (Empresa de Pesquisa Energética - EPE) is responsible for "promoting studies and producing information to support energy development plans and programs" (Brasil, 2004). As for the agriculture sector, it is the responsibility of the MAPA to aggregate "agricultural, meteorological, and climatological information for use in agriculture" (Brasil, 2019a).

In the environmental sector, it is important to mention two aspects: - according to the National Environment Policy (Política Nacional do Meio Ambiente - PNMA), energy, water, agriculture, other natural resources, and economic activities make up the environmental sector (Brasil, 1981);

- although multiple sectors include monitoring data from the environmental sector, this does not imply that there is integration between these different institutions and between the data monitored by them.

Once the institutional composition of each sector under analysis was identified, the main databases belonging to each sector were identified, as shown in the next section.

\section{Step 2: identification of the databases}

Based on the organizational system present in each sector, 35 national databases were identified (Table 2); they are distributed among their bodies and institutions. Of the databases surveyed, seven com- prised the water resources sector (20\%), eight comprised the energy sector (22.8\%), seven constituted the agricultural sector (20\%), and 13 made up the environmental sector (37.14\%).

In the water resources sector, different databases contain different information; of note are the: HIDROWEB, which can be highlighted for its pluviometric and fluviometric information; the reservoir monitoring system (Sistema de Acompanhamento de Reservatórios - SAR) for monitoring reservoirs; the grant registration for water volumes captured by different users distributed by hydrographic basin; the National Sanitation Information System (Sistema Nacional de Informações sobre Saneamento - SNIS) for monitoring the sanitation sector; the groundwater information system (Sistema de Informações de Água Subterrânea - SIAGAS) for groundwater; the National Dam Safety Information System (Sistema Nacional de Informações sobre Seguranca de Barragens - SNISB), which involves the registration of dams in the context of their safety; and the Metadata Portal for geographic information.

In the energy sector, the main databases include that of the $\mathrm{Na}$ tional Electric System Operator (Operador Nacional do Sistema Elétrico - ONS), which contains the operation history of the National Interconnected System (Sistema Interligado Nacional - SIN); the National Electric Energy Agency (Agência Nacional de Energia Elétrica - ANEEL) developed the ANEEL Generation Information System (Sistema de Informações de Geração da ANEEL - SIGA) to provide data on installed electricity generation capacity from its multiple sources in Brazil; the Union of Sugarcane Industries (União da Indústria de Canade-Açúcar - UNICA), which is not directly linked to the ministry of agriculture and energy, but which has a very rich database on the production and commercialization of sugarcane, ethanol production, and bioelectricity; open data from the ANP, which brings a large amount of historical information on the production of oil, natural gas, and biofuels, among many others; and the geographic information bases involving the SIN Cadastral Geographic Information System (Sistema de Informações Geográficas Cadastrais do SIN - SINDAT), the Geographic Information System for the Electricity Sector (Sistema de Informações Georreferenciadas do Setor Elétrico - SIGEL), the geographic information system for the energy sector (WEB MAP EPE/EPE), and the Information System Mining Geographic Areas (Sistema de Informações Geográficas da Mineração - SIGMINE).

In the agricultural sector, open data from the MAPA predominate; the National Institute of Meteorology (Instituto Nacional de Meteorologia - INMET), which provides a history of meteorological data; $\mathrm{CONAB}$, which provides the historical data on the Brazilian harvest, agricultural prices, production costs, and other information; documentary databases including the Agricultural Research Database (Base de Dados da Pesquisa Agropecuária - BDPA) of Brazilian Agricultural Research Corporation (Empresa Brasileira de Pesquisa Agropecuária EMBRAPA), and the Bibliographic Base of Brazilian Agriculture (Base Bibliográfica da Agricultura Brasileira - AGROBASE); the EMBRAPA Spatial Data Infrastructure (GEOINFO), which comprises a set of spa- 
WATER - ENERGY - AGRICULTURE - ENVIRONMENT SECTOR ORGANIZATION

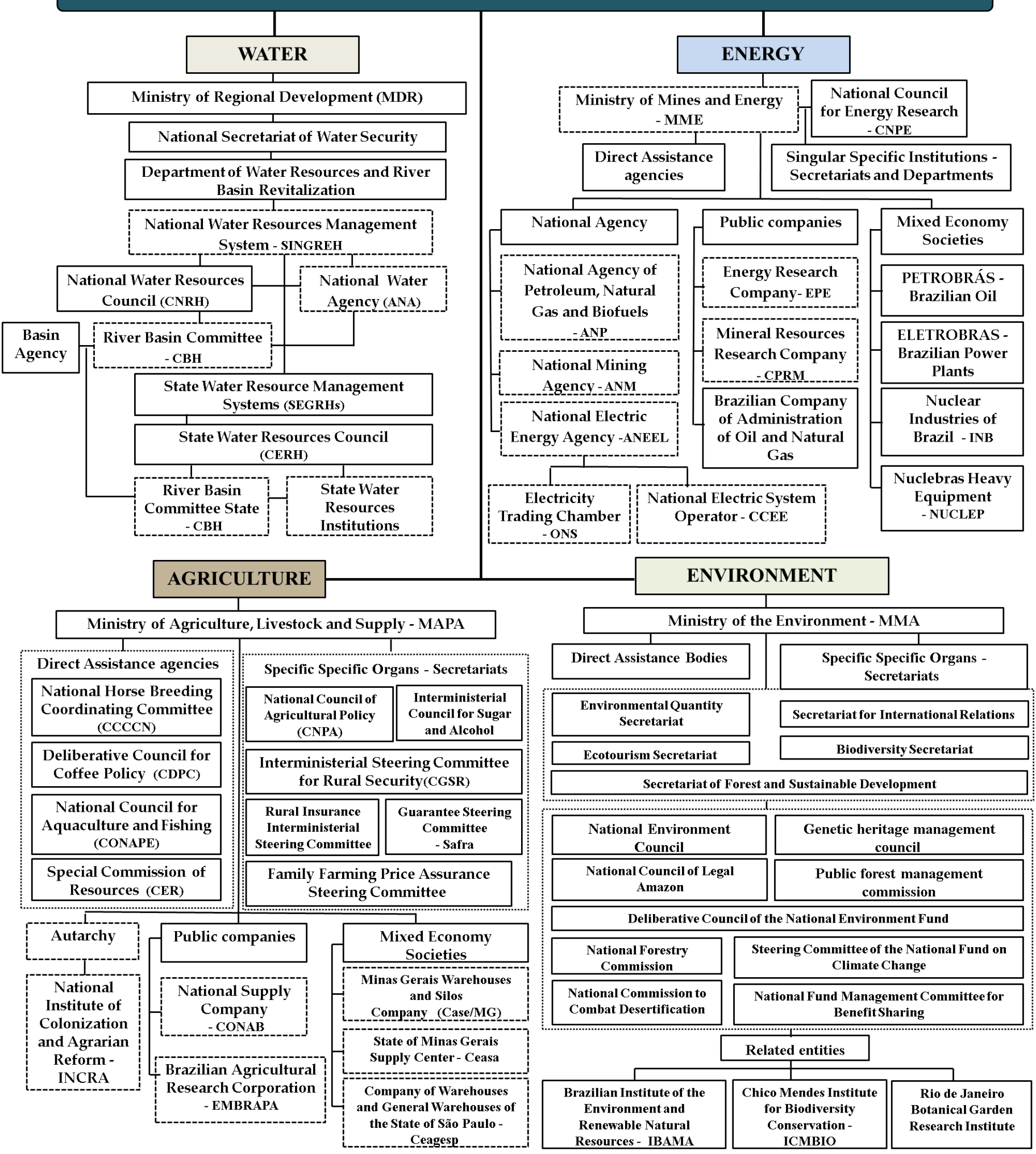

Figure 2 - Organization table of the Water - Energy - Agriculture - Environment sectors in Brazil.

Source: adapted from Torres et al. (2021). 
Table 2 - Main national databases of the Water-Energy-Agricultural-Environmental sectors.

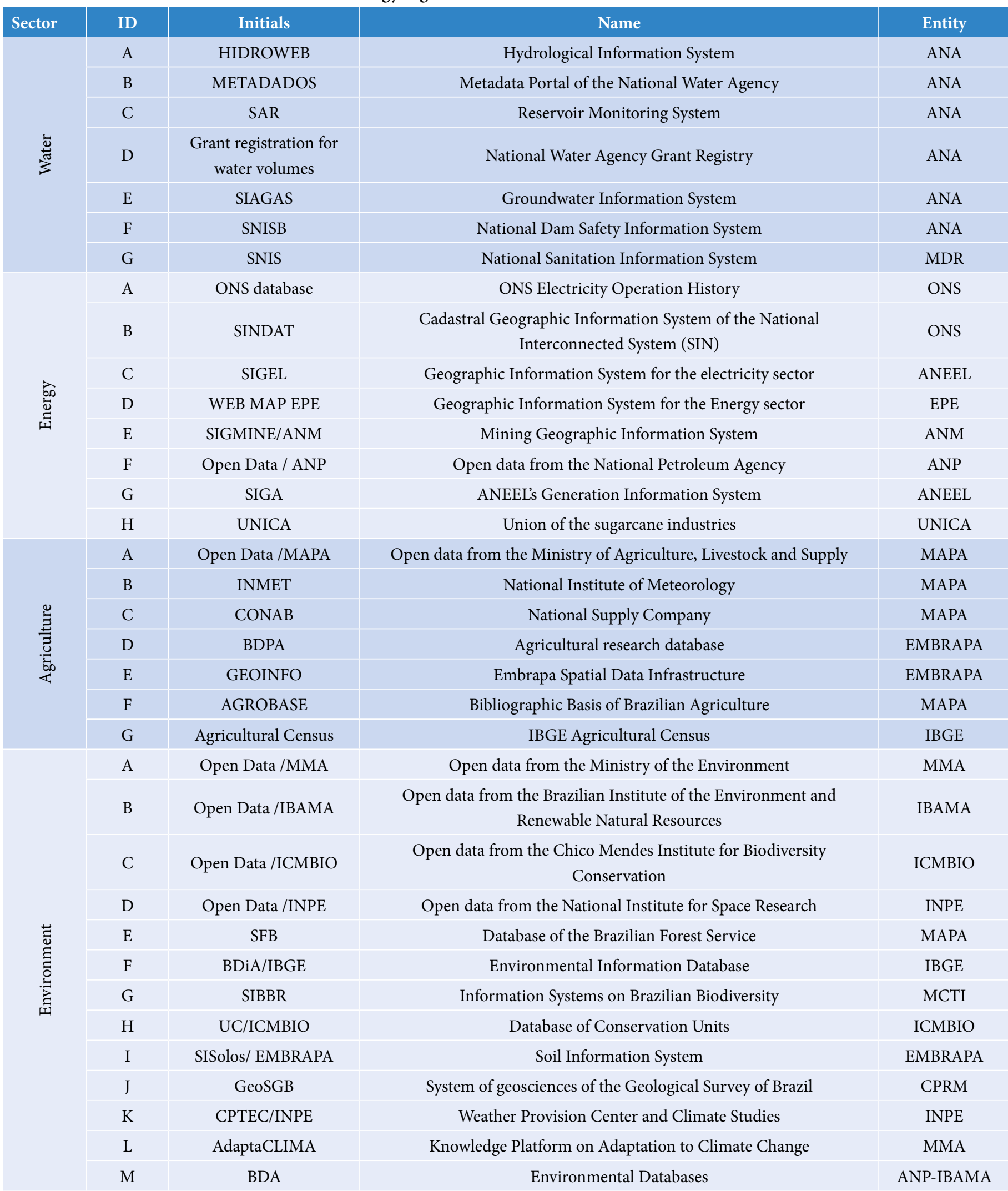


tial information; and the IBGE agricultural census. Although IBGE is not directly part of the agricultural sector, it has significant relevance in the collection of data through the Agricultural Census.

In the environmental sector, a large amount of information distributed in different institutions were highlighted, including: open data from the MMA; IBAMA; Instituto Chico Mendes for Biodiversity Conservation (ICMBIO) which includes information from Conservation Units, the National Institute for Space Research (Instituto Nacional de Pesquisas Espaciais - INPE), and the Weather Forecast and Climate Studies Center (Centro de Previsão de Tempo e Estudos Climáticos - CPTEC); the Brazilian Forest Service (Serviço Florestal Brasileiro - SFB), which comprises the National Forest Information System (Sistema Nacional de Informações Florestais - SNIF); the IBGE's Environmental Information Database (Banco de Dados de Informações Ambientais - BDiA), which addresses information on geology, geomorphology, pedology, and vegetation; the Brazilian Biodiversity Information System (Sistemas de Informações sobre a Biodiversidade Brasileira - SIBBR), a platform that brings together information about ecosystems; the Brazilian Soil Information System (Sistema de Informação de Solos Brasileiros - SISolos) of EMBRAPA, which has soil samples and profiles from all over Brazil; the System of Geosciences of the Geological Survey of Brazil (Sistema Geociências do Serviço Geológico do Brasil - GeoSGB) that deals with geological information from the national territory; and the Environmental Database (Sistema de Dados Ambientais - BDA) created by MMA Ordinance No. 422 of 10/26/11, which represents an integrated database between ANP and IBAMA.

Lawford (2019) states that social, economic, political, and biophysical data are essential for any integrated assessment of the water, energy, and agricultural sectors. The author also highlights some essential variables to enable studies contemplating the nexus approach: precipitation (pluviometric stations), air temperature, evapotranspiration, soil moisture (meteorological stations), water quality, operational and physical data of the reservoirs, flow (fluviometric stations), underground water, energy, land use, and occupation. Most of this information is present in the databases listed in Table 2; however, many of them do not cover all regions of the country, much information is out of date, and there is a disparity in the monitoring of data, both in terms of time and spatial scales. Torres (2020) adds that Brazil has a large number of inactive pluviometric and fluviometric monitoring posts, especially when it comes to small state hydrographic basins.

When inserting the environment into the context of integrated assessment, it is observed that, despite the significant number of databases illustrated in Table 2, most of the information available in the environmental databases is not integrated and does not interrelate, such as the Environmental Information Database with the Environmental Database.

Step 4 was taken from the identified databases, which conceives the analysis of its information. It should be mentioned that it was not necessary to present Step 3, since it involves the definition of the analysis criteria, that is, this phase has already been structured in the methodology of the study.

\section{Step 4: analysis of the databases}

The analysis of the databases was carried out through the investigation of five points, as listed in the methodology. For analysis of the first point, it was found that $74.3 \%$ of the databases surveyed in Table 2 were georeferenced, and were mostly distributed in the environmental, water, and energy sectors.

Spatial data greatly contributes to quantitative studies of integrated assessment of nexus elements. It enables research on multiple geographic scales if at least one of the following aspects are met:

- The presence of national databases that are spatialized and, at the same time, productive. They present the monitoring of their information and not just their characterization, and are able to mention HIDROWEB among the systems identified in Figure 2;

- Presence of georeferencing databases. In this case, it is necessary to integrate this information into a productivity database, such as the association between SIGEL and ONS.

As for the variability of the type of geographic scale to be worked on, cutouts of information present in a macro- to micro-scale can be made through the use of GIS tools. This is possible as long as the information is georeferenced and positioned within the geographical limits.

Several authors in the literature have pointed out significant benefits from the use of spatial data in different sectors of the economy. Gonçalves et al. (2009) developed a method based on a GIS to integrate physical data with the type and use of the soil to assist in the management and granting of the right to use groundwater applied in the DF. Souza and Farias (2010) provide in their study that the systematic organization in a GIS of the water resources sector and other related sectors facilitate the assessment and management of water in conservation units (UC). According to the authors, the integration between databases associated with the GIS allows a greater approximation of different public and private institutions that share specific themes in decision-making processes, which allows interoperability and cooperation between them (Souza and Farias, 2010). Pereira et al. (2019) addressed the relevance of spatial data and geological instruments to increase productivity and public capacity to define strategies to solve complex problems related to local geography.

Another point considered was the relationship between the organizational structure present in each sector and the geographical scale of the presentation of its data. In this case, it was observed that databases of the water resources sector normally present their data for the hydrographic basin scale, since the National Water Resources Policy (Política Nacional de Recursos Hídricos - PNRH) defines the hydrographic basin as a planning and management unit (Brasil, 1997a).

For the electricity sector, the main databases are for the regional scale (sub-systems), and depend on the functioning of the SIN. For the agricultural sector, CONAB presents information on the state and regional scales. The main information for the environment is presented on regional (biome), state, and national scales. 
The application of DSS for databases of other spatial scales allows the identification of the level of integration between them. For example, this can be used to verify the level of integration of the State grant registry with the ANA grant registration; integration of surface water availability with groundwater and its interrelationships with water quality; and demands for water and energy in the agricultural projects of the different regions of the country.

In addition to analyzing these issues, the databases were checked for the presence of divergences in the presented information. It should be considered that the investigation of this aspect is possible as long as more than one institution presents the same type of information for a given sector. This was conceivable only for the energy sector, where the WEB MAP EPE, SIGEL, SIGA, and ONS power generation history databases present information on the number of power plants present in the country.

The research revealed the presence of divergence between the quantities presented in these databases. For example, analyzing the number of wind farms, a total of 455 plants were found in the WEB MAP EPE database, 877 plants in SIGEL, 606 plants in SIGA, and 601 plants in ONS (considering the same time period for all). With regard to solar plants, 67 plants were identified on the WEB MAP EPE, 2,524 plants in SIGEL, 2,469 plants in SIGA, and 81 in ONS. The same is true for other power-generation plants.

In the water resources sector, Torres (2020) observed a disparity between the number of pluviometric and fluviometric stations reported in HIDROWEB for the number of active stations. For example, in the São Francisco River Basin (BHSF), the author identified that 32\% (567 of the total of 1,748$)$ of the river stations, and $53 \%(1,009$ of 1,878$)$ of the rain stations were deactivated.

After analyzing these aspects, an investigation was carried out on the presence of databases that integrate information from different sectors. In this case, the only databases (Table 2) that meet these requirements are:

- the grant registry/ANA, which lists the elements of water-irrigated agriculture, and water - energy (water demand for some types of energy, such as thermoelectric and hydroelectric);

- UNICA, which relates energy and agriculture (production of bioenergy from sugar cane);

- IBAMA, which brings multiple variables, such as biome-energy sources-solid waste;

- the Bank of Environmental Data shared between ANA-IBAMA (aimed at sharing different projects between ANP and IBAMA aiming at the optimization of the environmental licensing processes of the oil and gas industry in Brazil);

- the SNIS that relates the elements energy-water (consumption in the sanitation segment).

Specifically, for the registry of grant/ANA, it was observed that this database holds the geographic coordinates of the points of water col- lection for irrigation, and may represent the irrigated agriculture sector in terms of the location and number of the cultures practiced by the hydrographic basin.

As a last point of data analysis, nine national and international platforms were identified, which have information of interest for the sectors in question:

- National Spatial Data Infrastructure (Infraestrutura Nacional de Dados Espaciais - INDE);

- Information and Knowledge Management System for the Brazilian Semiarid Region (Sistema de Gestão da Informação e do Conhecimento do Semiárido Brasileiro - SIGSAB);

- Comex Stat: Database linked to the Ministry of Industry, Foreign Trade and Services;

- SIDRAS - IBGE database;

- PROCEL INFO: Energy efficiency information center;

- SISPPI - Information System on Public Irrigation Projects;

- DATAHIDRO-PETROBRÁS Corporate System on Water Resources and Effluents;

- UN Comtrade Database: UN database;

- FAOSTAT - Food and Agriculture Organization (FAO) database;

- WaterStat-Water footprint statistics.

All of these information systems, despite not being directly linked to the institutions listed in Figure 1, should be considered in the investigations contemplating the nexus concept as it contains a large amount of data measured for multiple spatial scales and contain open access data. For example, the information platform of the Brazilian semiarid region presents data on a regional scale, and the international database (WaterStat) displays information on the water footprint and virtual water of a wide variety of products and services.

In general, some aspects of interest in research related to the nexus concept have been discussed. However, other points of analysis deserve to be deepened, depending on the need for investigation for a given study.

\section{Step 5: classification of databases}

Table 3 lists the classification matrices of the databases listed in Table 2. It can be seen that more than $80 \%$ of the databases express information that is available for download; approximately $31.4 \%$ have a historical data monitoring period; the time scales most used as a data output format are annual (14.3\%) and multiple (37\%), which includes, annual, regional, and state data; more than $80 \%$ have multiple spatial scales, mainly national and state; more than $70 \%$ have multiple quantities; $37 \%$ represent more than one type of database (mainly characterization and productivity); and more than $50 \%$ are geo-referenced.

From the classification matrix, the databases were structured by sets of similarities in the information according to the categories presented in the criteria presented in Table 1 of the methodology. 


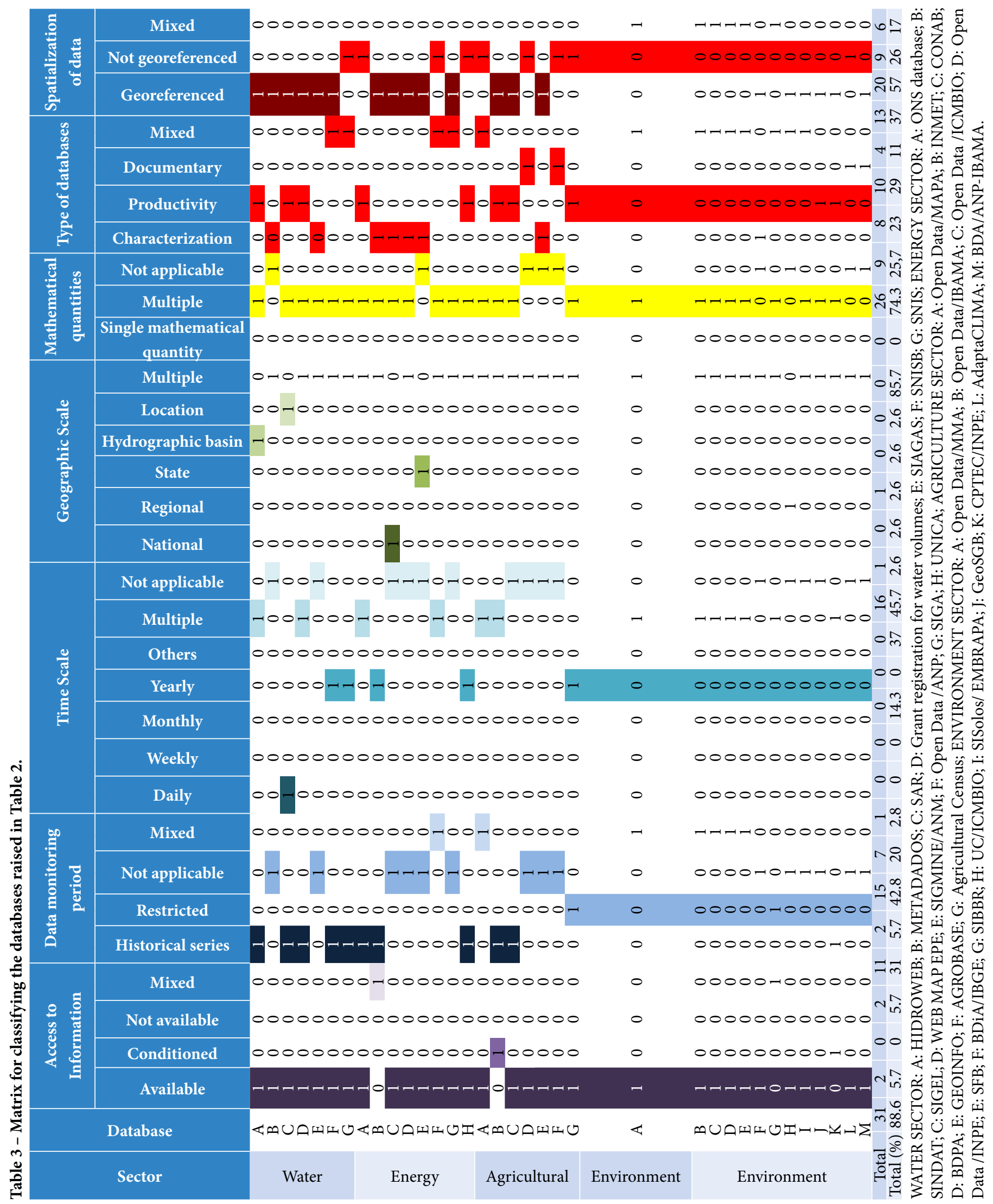




\section{Step 6: structuring and selecting databases}

This step represents the last phase of the DSS, in which the databases are structured and selected. For this process, a structure was elaborated that facilitated the visualization and selection of the databases (Figure 3). In this structure the databases are grouped by category according to the color scale presented in the methodology (Table 1). Database selection can be manual, or automated in Microsoft Excel. Figure 3 shows an example of filling in the structure according to the selection of certain criteria categories.

From the DSS application example (Figure 3), it is possible to analyze two aspects:

- the INMET, despite being present in practically all categories of the criteria reported in Figure 3. This database represents meteorological-climatological information and does not provide specific information related to agricultural productivity;

- despite the lack of databases in the agriculture sector to represent the hydrographic basin category, it can be seen that the registry of grant/ANA the water sector offers valuable information associated with the agricultural sector and can supplement this lack of data.
As for the energy and environmental sectors, the greatest lack of databases also consists of the geographical scale criterion referring to the hydrographic basin category. In the case of information from the environmental sector, this deficiency can be addressed as long as the databases are georeferenced, allowing integration with multiple spatial scales through GIS tools. When viewing the results in the DSS structure, two directions tend to be considered: the first corresponds to the possibility of changing from a more restrictive category to a less restrictive one to serve all sectors under analysis; the second involves choosing to remain in restrictive categories even though they do not include all the databases of the different sectors. This assumes the necessary simplifications and limitations in the development of an integrated study.

In view of the structure presented in Figure 3 the development of the steps presented in the methodology was conducted for the databases indicated in Table 2. The discussions exposed in the development of the steps do not consider other data systems. Therefore, in the case of insertion of new databases or application to other territorial limits the methodological, procedure must be adjusted or implemented again and new investigations must be considered.

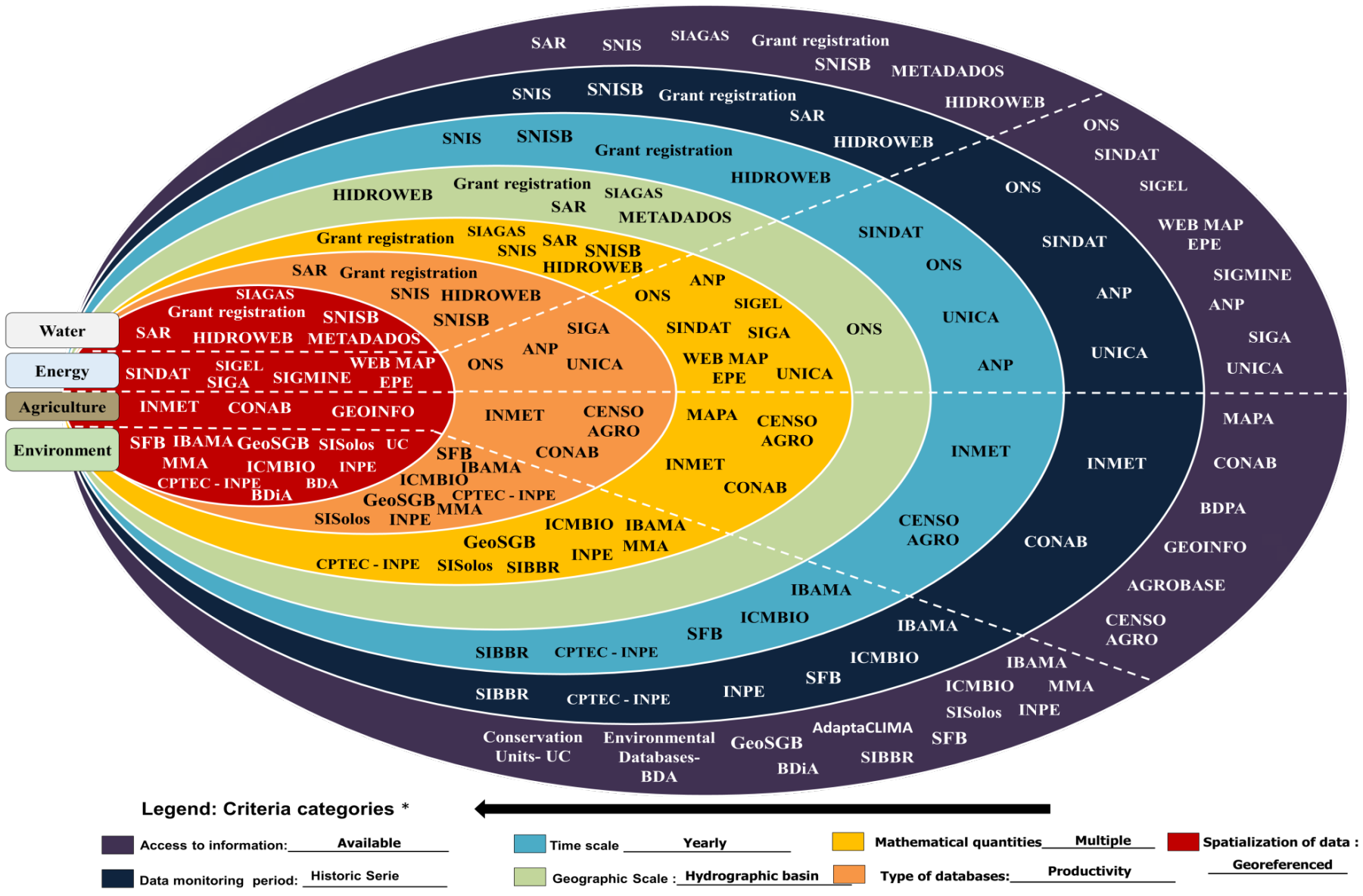

Figure 3 - Structure to assist in the selection of databases in a DSS - Example of filling.

${ }^{\star}$ As the categories are modified. the structure's filling colors and databases are also changed. 


\section{Applicability of DSS in public management}

Complex and multidimensional problems involving different sectors of the government require systematic databases that enable the integration of information. The lack of an information system or the lack of integration between the data generated by different sectors, often cause overlapping of projects (Cisne, 2012), misaligned or weak decision-making processes, and wastage of time and money.

According to Rosales-Asensio et al. (2020), access and integration of databases represent a major challenge for the management of natural resources. The compilation of standardized data can help to deal with problems related to consistency, comparability and scale, in addition to the lack of information from certain sectors (Rosales-Asensio et al., 2020).

In this sense, the DSS proposed in the present study, based on the "Nexus of water-energy-agriculture-environment" approach is a new tool for public managers to assist in investigating the level of compatibility and data leveling between information present in different databases. The DSS represents a powerful tool for identifying and organizing problems, analyzing different alternatives, and determining the best course of action (Porto et al., 2003; Ahmadi et al., 2020). For this, it is essential to automate the DSS for time optimization and its application to databases covering other sectors and spheres of government, whether they are from the union, state, or municipal.

Therefore, any plan, program or project that involves multiple sectors can use the DSS. This system aims to optimize planning and contribute to a better decision-making process and definition of integrated strategies, which tend to be reflected in greater efficiency and effectiveness.

\section{Conclusion}

The DSS proposed in the present study has the main purpose of assisting the development of integrated and interdependent studies (nexus concept) of a quantitative character. From the application of the DSS to the databases of the water, energy, agricultural, and environmental sectors present in the Brazilian context, it was possible to point out some limitations of this approach as well as future directions.

\section{Limitations}

- In general, the information corresponding to the sectors analyzed is dispersed in different institutions and does not have data standardization or uniformity; that is, most databases were structured to answer the demands of their sectors, without the prospect of integration with data from other sectors;

- The uniformity of some information is difficult to achieve, especially when it involves different spatial and time scales. In the case of spatial scales, standardization becomes easier when the data are georeferenced;

- To date, there are no national databases in the country that make it possible to investigate the impacts of water use by power plants (thermoelectric, solar, oil, coal, and natural gas) on the water availability of the hydrographic basins where they are located (systems water allocation);
- In the energy to water (sanitation) relationship, the database that stands out is the SNIS; however, it does not present the energy consumption in the different stages of the process;

- In the environmental sector, a large number of elements are at play, and consequently, it has the largest number of databases. However, in most cases, the information is not related to data from other sectors;

- Some interactions between water, energy, agriculture, and the environment cannot be developed by considering the analyzed databases; for example, energy consumption in irrigated agriculture and consumption of water and energy for all types of energy in the Brazilian matrix.

\section{Directions and recommendations}

- The adoption of macro-scales, spatial (national), and temporal (annual) uniformity facilitates the integration of the information collected. In general, working with micro- scales (such as small hydrographic basins) makes it difficult to develop integrated studies because of the low quantity of monitoring data; however, the micro-scale does facilitate database development in terms of reducing the number of variables accounted for in the process;

- It is necessary to link the georeferenced databases with the productivity databases;

- The databases of the energy sector, which may mention SIGA/ ANEEL and ANP, should expand their information in the plant's register. For example, for thermoelectric plants and oil refineries, the type of cooling system, type of thermodynamic cycle, fuel used, and water situation in the region where they are located should be recorded;

- The agricultural and energy sectors should structure an integrated database combining different energy crops for the production of biofuels. The UNICA database for sugarcane is a fine example; however, it could be expanded to contain other information such as energy consumption, and water and energy use in production;

- It is recommended to apply the proposed procedure to databases present in other entities of the Federation, and to expand analyses to global databases, mainly related to the environmental and agricultural sectors. It is also recommended to structure integrated databases between the sectors involved, aiming at greater leveling and uniformity in the presentation of information. Doing so will reduce uncertainties and direct systemic planning and management strategies.

\section{Acknowledgments}

We, the authors, wish to thank the Interdisciplinary Center for Energy and Environment (CIEnAm) from Universidade Federal da Bahia, Brazil, for all the technical support. 


\section{Contribution of authors:}

Torres, C.J.F.: Introduction, Conceptualization, Methodology, Formal analysis, Investigation, Data curation, Writing - original draft; Silva, R.S.X.: Introduction, Methodology, Formal analysis, Investigation, Data curation, Writing - original draft; Fontes, A.S.: Formal analysis, Investigation, Conclusion, Writing - review \& editing; Ribeiro, D.V.: Formal analysis, Investigation, Writing - review \& editing; Medeiros, Y.D.P.: Formal analysis, Investigation, Writing - review \& editing.

\section{References}

Abers, R.N.; Jorge, K.D., 2005. Descentralização da gestão da água: por que os comitês de bacia estão sendo criados? Ambiente \& Sociedade, v. 8, (2), 99-124 http://dx.doi.org/10.1590/S1414-753X2005000200006

Ahmadi, A.; Kerachian, R.; Skardi, M.J.E.; Abdolhay, A., 2020. A stakeholderbased decision support system to manage water resources. Journal of Hydrology, v. 589, 125138. https://doi.org/10.1016/j.jhydrol.2020.125138

Albrecht, T.R.; Crootof. A.; Scott, C.A., 2018. The Water-Energy-Food Nexus: A systematic review of methods for nexus assessment. Environmental Research Letters, v. 13, (4), 043002. https://doi.org/10.1088/1748-9326/aaa9c6

Allouche, J.; Middleton C.; Gyawali, D., 2015. Technical Veil. Hidden Politics: Interrogating the Power Linkages behind the Nexus. Water Alternatives, v. 8, (1), 610-626

Al-Saidi, M.; Elagi, N.A., 2017. Towards understanding the integrative approach of the water. energy and food nexus. Science of the Total Environment, v. 574, 1131-1139. https://doi.org/10.1016/j. scitotenv.2016.09.046

Baleta, J.; Mikulcic, H.; Klemes, J.J.; Urbaniec, K.; Duic, N., 2019. Integration of energy. water and environmental systems for a sustainable development. Journal of Cleaner Production, v. 215, 1424-1436. https://doi.org/10.1016/j. jclepro.2019.01.035

Bamwesigye, D.; Hlavackova, P.; Darkwah, S.A.; Verter, D., 2019. Deforestation. Climate Change and Food Security Nexus in SubSahara Africa: Content Analysis. https://doi.org/10.20944/preprints201902.0154.v1

Bizikova, L.; Roy, D.; Swanson, D.; Venema, H.D.; McCandless, M., 2013. The Water-Energy-Food Security Nexus: Towards a practical planning and decision-support framework for landscape investment and risk management. The International Institute for Sustainable Development.

Brasil. 1981. Lei no 6.938. de 31 de agosto de 1981. Diário Oficial da União.

Brasil. 1988. Constituição da República Federativa do Brasil de 1988. Diário Oficial da União.

Brasil. 1991. Lei no 8.171, de 17 de janeiro de 1991. Diário Oficial da União. Brasil. 1997a. Lei no 9.433, de 8 de janeiro de 1997. Diário Oficial da União. Brasil. 1997b. Lei no 9.478, de 6 de agosto de 1997. Diário Oficial da União. Brasil. 2004. Lei no 10.847, de 15 de março de 2004. Diário Oficial da União. Brasil. 2011. Decreto no 140, de 8 de dezembro de 2011. Diário Oficial da União. Brasil. 2016. Decreto no 8.777, de 11 de maio de 2016. Diário Oficial da União Brasil. 2019a. Decreto no 9.667, de 2 de janeiro de 2019. Diário Oficial da União. Brasil. 2019b. Decreto n 9.672, de 2 de janeiro de 2019. Diário Oficial da União. Brasil. 2019c. Decreto no 9.675, de 2 de janeiro de 2019. Diário Oficial da União. Brasil. 2019d. Lei n 13.844, de 18 de junho de 2019. Diário Oficial da União. Brasil. 2020. Decreto nº 10.290, de 24 de março de 2020. Diário Oficial da União.
Chang, Y.; Li, G.; Yao, Y.; Zhang, L.; Yu, C., 2016. Quantifying the WaterEnergy-Food Nexus: Current Status and Trends. Energies, v. 9, (2), 65. http:// doi.org/10.3390/en9020065

Cisne, J.J.N. 2012. Intersetorialidade como um novo paradigma para a gestão pública focada em resultado: análise dos projetos de combate à pobreza no Ceará. In: XXXV Encontro da ANPAD. Rio de Janeiro.

Dai, J.; Wu, S.; Han, G.; Weinberg, J.; Xie, X.; Wu, X.; Song, X.; Jia, B.; Xue, W.; Yang, Q., 2018. Water-energy nexus: A review of methods and tools for macro-assessment. Applied Energy, v. 210, 393-408. https://doi.org/10.1016/j. apenergy.2017.08.243

Eftelioglu, E.; Jiang, Z.; Ali, R.; Shekhar, S., 2016. Spatial computing perspective on food energy and water nexus. Journal of Environmental Studies and Sciences, v. 6, 62-76. https://doi.org/10.1007/s13412-016-0372-y

Embid, A.; Martín, L., 2018. Lineamientos de políticas públicas: Un mejor manejo de las inter-relaciones del Nexo entre el agua. la energia y la alimentación. CEPAL - Serie Recursos Naturales e Infraestructura. n. 189.

Endo, A.; Tsurita, I.; Burnett, K.; Orencio, P.M., 2017. A review of the current state of research on the water.energy. and food nexus. Journal of Hydrology: Regional Studies, v. 11, 20-30. https://doi.org/10.1016/j.ejrh.2015.11.010

Gonçalves, T.D.; Roig, H.L.; Campos, J.E.G., 2009. Sistema de informação geográfica como ferramenta de apoio à outorga dos recursos hídricos subterrâneos no Distrito Federal. Revista Brasileira de Geociências, v. 39, (1), 169-180.

Hajkowicz, S.; Collins, K., 2007. A review of multiple criteria analysis for water resource planning and management. Water Resources Management, v. 21, 1553-1566. https://doi.org/10.1007/s11269-006-9112-5

Hanlon, P.; Madel, R.; Olson-Sawyer, K.; Rabin, K.; Rose, J., 2013. Food, Water and Energy: Know the nexus. GRACE - Communications Foundation Water and Energy Programs.

Hoff, H., 2011. Understanding the Nexus. Background Paper for the Bonn 2011. Conference: The Water. Energy and Food Security Nexus. Stockholm Environment Institute.

Huckleberry, J.K.; Potts, M.D., 2019. Constraints to implementing the food-energywater nexus concept: Governance in the Lower Colorado River Basin. Environmental Science \& Policy, v. 92, 289-298. https://doi.org/10.1016/j.envsci.2018.11.027

King, C.W.; Carbajales-Dale, M., 2016. Food-energy-water metrics across scales: project to system level. Journal of Environmental Studies and Sciences, v. 6, 39-49. https://doi.org/10.1007/s13412-016-0390-9

Lawford, R., 2019. A Design for a Data and Information Service to Address the Knowledge Needs of the Water-Energy-Food (W-E-F) Nexus and Strategies to Facilitate Its Implementation. Frontiers in Environmental Science, v. 7. https:// doi.org/10.3389/fenvs.2019.00056

Lawford, R.; Bogardi, J.; Marx, S.; Jain, S.; Wostl, C.P.; Knüppe, K.; Ringler, C.; Lansigan, F.; Meza, F., 2013. Basin perspectives on the Water-Energy-Food Security Nexus. Current Opinion in Environmental Sustainability, v. 5, (6), 607-616. https://doi.org/10.1016/j.cosust.2013.11.005 
Leese, M.; Meisch, S., 2015. Securitising Sustainability? Questioning the 'Water. Energy and Food-Security Nexus'. Water Alternatives, v. 8, (1), 695-709.

Maas, A.; Dozier, A.; Manning, D.T.; Goemans, C., 2017. Water storage in a changing environment: The impact of allocation institutions on value. Water Resources Research, v. 53, (1), 672-687. https://doi. org/10.1002/2016WR019239

McGrane, S.J.; Acuto, M.; Artioli, F.; Chen, P.-Y.; Comber, R.; Cottee, J.; FarrWharton, G.; Green, N.; Helfgott, A.; Larcom, S.; McCann, J.A.; O’Reilly, P.; Salmoral, G.; Scott, M.; Todman, L.C.; Gevelt, T.V.; Yan, X., 2019. Scaling the nexus: Towards integrated frameworks for analysing water. energy and food. The Geographical Journal, v. 185, (4), 419-431. https://doi.org/10.1111/ geoj.12256

Meldrum, J.; Nettles-Anderson, S.; Heath, G.; Macknick, J., 2013. Life cycle water use for electricity generation: a review and harmonization of literature estimates. Environmental Research Letters, v. 8, 015031. https://doi. org/10.1088/1748-9326/8/1/015031

Meng, F.; Liu, G.; Liang, S.; Su, M.; Yang, Z., 2019. Critical review of the energy-water-carbon nexus in cities. Energy, v. 171, 1017-1032. https://doi. org/10.1016/j.energy.2019.01.048

Mercure, J-F.; Paim, M.A.; Bocquillon, P.; Lindner, S.; Salas, P.; Martinelli, P.; Berchin, I.I.; Andrade Guerra, J.B.S.O.; Derani, C.; Albuquerque Junior, C.L.; Ribeiro, J.M.P.; Knobloch, F.; Pollitt, H.; Edwards, N.; Holden, P.; Foley, A.; Schaphoff, S.; Faraco, R.; Vinuales, J., 2019. System complexity and policy integration challenges: The Brazilian Energy- Water-Food Nexus. Renewable and Sustainable Energy Reviews, v. 105, 230-243. https://doi.org/10.1016/j. rser.2019.01.045

Miralles-Wilhelm, F., 2016. Development and application of integrative modeling tools in support of food-energy-water nexus planning - a research agenda. Journal of Environmental Studies and Science, v. 6, 3-10. https://doi. org/10.1007/s13412-016-0361-1

Moioli, E.; Salvati, F.; Chiesa, M.; Siecha, R.T.; Manenti, F.; Laio, F.; Rulli, M.C. 2018. Analysis of the current world biofuel production under a water-foodenergy nexus perspective. Advances in Water Resources, v. 121, 22-31. https:// doi.org/10.1016/j.advwatres.2018.07.007

Nhamo, L.; Ndlela, B.; Nhemachena, C.; Mabhaudhi, T.; Mpandeli, S.; Matchaya, G., 2018. The Water-Energy-Food Nexus: Climate Risks and Opportunities in Southern Africa. Water, v. 10, (5), p. 567. https://doi. org/10.3390/w10050567

Pereira, M.M.; Maciel, A.L.S.; Melo, P.R.; Fontenele, S.B., 2019. Sistema de informação geográfica como ferramenta de subsídio a gestão pública no Brasil. In: XIX Simpósio Brasileiro de Sensoriamento Remoto. Santos.

Porto, R.L.L.; Roberto, A.N.; Schardong, A.; Méllo Júnior, A.V.; Teixeira, C.A.; Oliveira, C.P.M.; Castro, H.L.; Palos, J.C.F.; Zahed Filho, K.; Porto, M.; Carvalho, M.A.; Marcellini, S.S., 2003. Sistema de suporte a decisão para análise de sistemas de recursos hídricos. In: Silva, R.C.V. (Eds.), Métodos numéricos em recursos hídricos. ABRH, Porto Alegre, pp. 206.
Rosales-Asensio, E.; Puente-Gil, A.; Garcia-Moya, F.-J.; Blanes-Peiró, J.; Simón-Martín, M., 2020. Decision-making tools for sustainable planning and conceptual framework for the energy-water-food nexus. Energy Reports, v. 6, (suppl. 6), 4-15. https://doi.org/10.1016/j.egyr.2020.08.020

Sanders, K.T.; Masri, S.F., 2016. The Energy-Water-Agriculture Nexus: The Past. Present and Future of Holistic Resource Management. Journal of Cleaner Production, v. 117, 73-88. https://doi.org/10.1016/j.jclepro.2016.01.034

Shannak, S.; Mabrey, D.; Vittorio, M., 2018. Moving from theory to practice in the water-energy-food nexus: An evaluation of existing models and frameworks. Water-Energy Nexus, v. 1, (1), 17-25. https://doi.org/10.1016/j.wen.2018.04.001

Souza, L.M.S.; Farias, O.L.M., 2010. Sistema de Informações Geográficas para gerenciamento de recursos hídricos em unidades de conservação utilizando a estrutura de dados geográficos vetoriais - EDGV. Revista Brasileira de Cartografia, v. 63, (1), 11.

Torres, C.J.F., 2020. Bases Metodológicas para a Inserção do Conceito Nexus Água - Energia - Agricultura em Modelos Intersetoriais de Planejamento e Gestão. Tese de Doutorado, Universidade Federal da Bahia, Salvador, 389 pp.

Torres, C.J.F.; Lima, C.H.P.; Fontes, A.S.; Ribeiro, D.V.; Moreira, I.T.A.; Medeiros, Y.D.P., 2021. A method for classifying interrelation between sectoral regulatory laws and the "water-energy-agriculture nexus concept" in Brazil. Water Supply. https://doi.org/10.2166/ws.2021.036

Torres, C.J.F.; Lima, C.H.P.; Goodwin, B.S.A.; Aguiar Junior, T.R.; Fontes, A.S.; Ribeiro, D.V.; Silva, R.S.X.; Medeiros, Y.D.P., 2019. A Literature Review to Propose a Systematic Procedure to Develop "Nexus Thinking" Considering the Water-Energy-Food Nexus. Sustainability, v. 11, (24), 7205. https://doi. org/10.3390/su11247205

Urbaniec, K.; Mikulčić, H.; Rosen, M.A.; Duić, N., 2017. A Holistic Approach to Sustainable Development of Energy. Water and Environment Systems. Journal of Cleaner Production, v. 155, (part 1), 1-11. https://doi.org/10.1016/j. jclepro.2017.01.119

Walker, R.V.; Beck, M.B.; Hall, J.W.; Dawson, R.J.; Heidrich, O., 2014. The energy-water-food nexus: Strategic analysis of technologies for transforming the urban metabolism. Journal of Environmental Management, (141), 104-115. https://doi.org/10.1016/j.jenvman.2014.01.054

World Economic Forum (WEF). 2011. Water security: the water-food-energyclimate nexus. Island Press, Washington, D.C.

Wicaksono, A.; Jeong, G.; Kang, D., 2017. Water. energy. and food nexus: review of global implementation and simulation model development. Water Policy Uncorrected Proof, v. 19, (3), 440-462. https://doi.org/10.2166/wp.2017.214

Wu, M.; Chiu, Y., 2011. Consumptive Water Use in the Production of Ethanol and Petroleum Gasoline - 2011 Update (Accessed December, 2020) at: https://greet.es.anl.gov/publication-consumptive-water

Zhang, P.; Zhang, L.; Chang, Y.; Xu, M.; Hao, Y.; Liang, S.; Liu, G.; Yang, Z.; Wang, C., 2019. Food-energy-water (FEW) nexus for urban sustainability: A comprehensive Review. Resources, Conservation \& Recycling, v. 142, 215-224. https://doi.org/10.1016/j.resconrec.2018.11.018 